\title{
A HAZAI MÉHÉSZETI ÁGAZAT HELYZETÉNEK ELEMZÉSE (TERMELÉS, KERESKEDELEM)
}

\author{
- Sh- \\ SITUATION ANALYSIS OF THE HUNGARIAN BEEKEEPING SECTOR \\ (PRODUCTION, TRADE) \\ - \\ FEKETÉNÉ FERENCZI, ALIZ \\ SZÜCS, ISTVÁN \\ VIDA, VIKTÓRIA \\ \$a. \\ Debreceni Egyetem, Gazdaságtudományi Kar, Gazdálkodástudományi Intézet \\ (University of Debrecen, Faculty of Economics and Business, Institute of Applied Economics Sciences) \\ H-4032 Debrecen, Böszörményi út 138. \\ e-mail: ferenczi.aliz@econ.unideb.hu
}

(1)

From year to year, the global production of honey is continuously growing, but the honey producers and other stakeholders around the world and in Europe face similar processes and difficulties that are destroying the honey market. It would be necessary to reduce counterfeiting, improve the bee health situation, operate a comprehensive database and monitoring system, and provide extensive support to beekeepers. In order to ensure the sustainability of the beekeeping sector, it is necessary to develop and apply good agricultural practices, and in order to preserve biodiversity, related rural development programs and measures are needed. If the sector stabilizes (in Hungary, in EU-28 and worldwide), the long-term sustainability of beekeeping can be achieved; its ecological significance can be protected, and the rural retention role of the countryside may be strengthened in honey-producing countries. The aim of the study is to map the EU and Hungary honey production and trade with the help of relevant literature and statistics, and to present the current situation, difficulties and challenges of the honey market. After analyzing the market situation and sectoral processes, a SWOT matrix has been created including the strengths, weaknesses, opportunities and threats of the beekeeping sector. Then we made recommendations to improve the current situation in the beekeeping sector.

KuLCSSZAVAK: méhészet, fenntarthatóság, méztermelés, méz kereskedelem
KEYwORDS: beekeeping, sustainability, honey production, honey trade

JEL-KóD (JEL CODE): Q13

DOI: https://doi.org/10.20494/TM/8/2/2 


\section{BEVEZETÉS - INTRODUCTION}

A méhészeti ágazat a mezőgazdaságon belül kis arányt képvisel, azonban annak szerves része és jelentősége nem elhanyagolható. A méhészet a méz és egyéb méhészeti termékek előállításán túl fontos szerepet tölt be az ökoszisztéma, a biológiai sokféleség fenntartásában a növények beporzásán keresztül (ORAVECZ et al., 2020 a). Az ENSZ Élelmezési és Mezőgazdasági Szervezetének (FAO) kutatása szerint a beporzó rovarok koncentrációjának és sokszínüségének növelése közvetlen hatással van a terméshozamokra, a termelők átlagos termelékenységének növelésére (EP, 2018). PATEL és munkatársai (2021) kutatásai szerint a méhek a beporzásban betöltött szerepük mellett képesek az ENSZ által megfogalmazott 17 fenntartható fejlődési célkitűzés közül 15 teljesüléséhez hozzájárulni.

A Codex Alimentarius 1981-ben jóváhagyott meghatározása szerint a méz természetes termék, amelyhez nem adható hozzá, illetve amelyből nem vonható ki semmiféle anyag, és amely nem szárítható a méhkaptáron kívül. Ezt az irányadó meghatározást vette át később a Mézirányelvként is ismert, EURÓPAI TANÁCS (2001) 2001/110/EK irányelve, valamint a Magyar Élelmiszerkönyv 2002-ben jóváhagyott 1-3-2001/110. számú előírása (SZABÓ, 2020). Ezek a dokumentumok rögzítik továbbá az egyes mézfajtákat és azok összetételének minőségi követelményeit is.

A világon mindenhol foglalkoznak méhtartással, de különböző termelési feltételek, hozamok, technológiák és méhészeti gyakorlatok jellemzőek (ÁRVÁNÉ, 2011). Vannak azonban hasonló kihívások, melyekkel az ágazat szereplőinek meg kell küzdeniük, mint a méhegészségügyi helyzet, a mézhamisítás, a klímaváltozás, az alacsony árak.

$\mathrm{Az}$ utóbbi években kialakult súlyos méhegészségügyi helyzet (a gyorsan terjedő méhbetegségek, méhpusztulások, kaptárelhagyások) miatt a méhészeti ágazat világszerte nehézségekkel küszködik (ORAVECZ et al., 2020 ). A méhcsaládok pusztulása akadályozza a méhészet fenntarthatóságát és növeli a méz kereslete és kínálata közötti egyensúlytalan helyzetet. Pedig a méhek egészségi állapotára úgy tekinthetünk, mint a környezeti minőség fontos biológiai indikátorára (PAPP, 2015). A Föld élelemkészletének egyharmada közvetlenül vagy közvetve függ a rovarok megporzó képességétől. Tehát a megporzó rovarok egészsége és a méhészeti ágazat fenntartása is egyre fontosabb (ÁRVÁNÉ, 2011).

Ezekhez a problémákhoz adódik még a mézhamisítások okozta nehézségek (a méz a harmadik leginkább hamisított élelmiszer az olívaolaj és a tej után), valamit a méhészek számára kedvezőtlenül alakuló árak (EP, 2018). A hamis és olcsó méz behozatala veszélyezteti a méhészetet az egész világon és súlyos következményekkel jár a világ élelmiszertermelésére nézve is (TAMMA, 2017).

A klímaváltozásnak közvetlen hatása van a méztermelésre, mivel a hőmérséklet alapvetően befolyásolja a nektártermelést, kiszámíthatatlanná teheti a mézhozam alakulását. Az időjárásból fakadó rendellenességek a virágzó növények viselkedését hátrányosan befolyásolják, ami többek között a korlátozott nektártermelésben is megnyilvánul (TÓTH, 2020). Például a magas hozzáadott értékű akácnak (Magyarország, Olaszország) vagy levendulának (Franciaország) az elmúlt évek kedvezőtlen időjárása a terméseredmény csökkenését okozta. Ez súlyosan érinti a méhészeket, mivel e két növény az adott területeken a bevétel több, mint 50\%át teszi ki (PÁLYI, 2020 $)$.

A méhészet kulcsszerepet játszik a világ és Európa mezőgazdaságában. Azon túl, hogy az ágazat hozzáadott értéke évente mintegy 1 milliárd euró, a méhek megporzási tevékenysége, mely alapvető tényező a termesztett és vad növények, illetve a gyümölcsfák megtermékenyítésében, legalább 22 milliárd euróval járul hozzá az európai mezőgazdaság eredményéhez. A méhészeknek tehát óriási szerepük van a vidéki területek fenntartható fejlődésében és a biológiai sokféleség fenntartásában, tevékenységük társadalmi és környezeti közjószágot nyújt (PAPP, 2015). 


\section{SZAKIRODALMI ÁTTEKINTÉS -} LITERATURE REVIEW

\subsection{Az Európai Unió méztermelése és kereskedelme - Honey Production and Trade in the European Union}

Az Európai Unió a világ egyik legnagyobb méztermelője és egyben legnagyobb mézimportőre. Az európai mezőgazdaság számára rendkívül fontos a méhtartás, a méhek beporzó tevékenysége, valamint azon európai méhészek számára is, akik megélhetését jelenti a méhészeti tevékenyégből származó bevétel (PÁLYI, 2020). Az EU-ban a megtermelt méz mennyiségének alakulását elemezve megállapítható, hogy a 2015. évi kiugróan magas termést (259,3 ezer tonna) a következő években nem sikerült elér- ni. Az Unióban a 2019. évi méztermés mennyisége (241,1 ezer tonna) az előző évhez képest csökkentő tendenciát mutat a fő méztermelő és exportáló országok esetében (PÁLYI, 2020 ). Az EU legnagyobb méztermelőit az 1. ábra mutatja.

Méhészettel az EU minden tagállamában foglalkoznak, a méhészeti programokhoz bejelentett adatok alapján az EU-ban 2019-ben 615 ezer méhész, összesen mintegy 18,2 millió méhcsaládot gondozott, ami a 2018. évi adatokhoz képest 8,3\%-os növekedést jelentett. Az európai méhcsaládszám 2017-ben volt a legkevesebb 16,66 millió, majd fokozatos emelkedés következett 2018-ban 17,58 millió, ami 2019-re 18,21 millióra változott. A hosszú távú tendencia is azt mutatja, hogy az elmúlt évtized során emelkedett a méhcsaládok száma az EU-ban (EB, 2019).

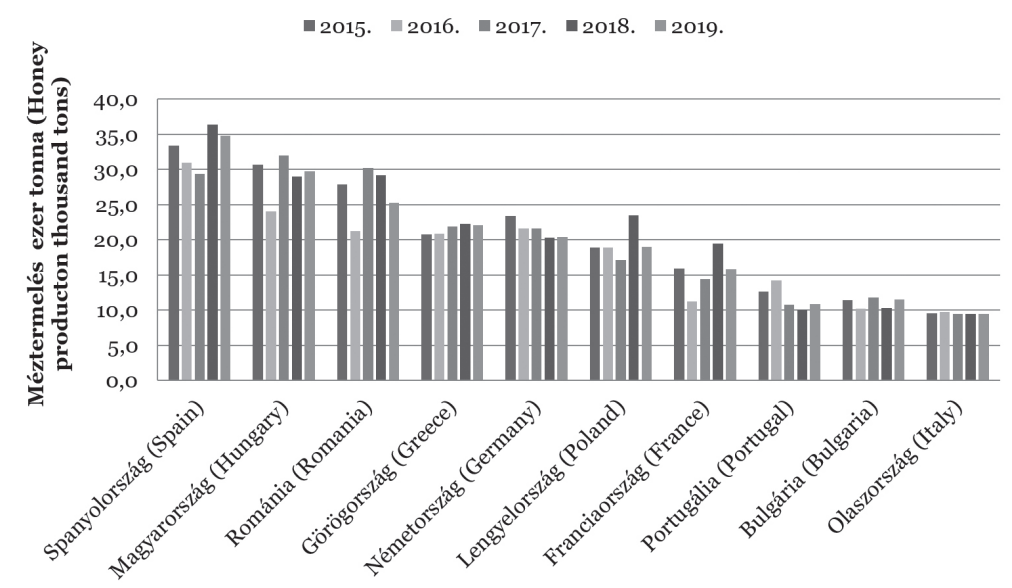

1. ÁBRA

\section{Az EU legnagyobb méztermelői 2015-2019 között}

FIG. 1

A 2015-2019 közötti időszakban realizált uniós mézexport enyhén változó eredményeinek adatai a 2. ábrán láthatók, mely szerint az export jelentős része EU-n belül történik. Az Unióból más országokba irányuló mézexport elhanyagolható mértékü, 2018-ban az Eurostat adatai alapján az uniós termelés kb. 13,1\%-át, 2019-ben 12,3\%-át exportálta. Fő piacai Svájc, Szaúd-Arábia, USA, Japán. Az unión kívüli országokba irányuló kivitel esetén az átlagos export ár 5,89 EUR/kg volt 2019-ben, 2018ban csak 5,71 EUR/kg, legmagasabb a 2017. évi 5,95 EUR/kg átlagos ár volt (EB, 2019). 


\section{2. ÁBRA}

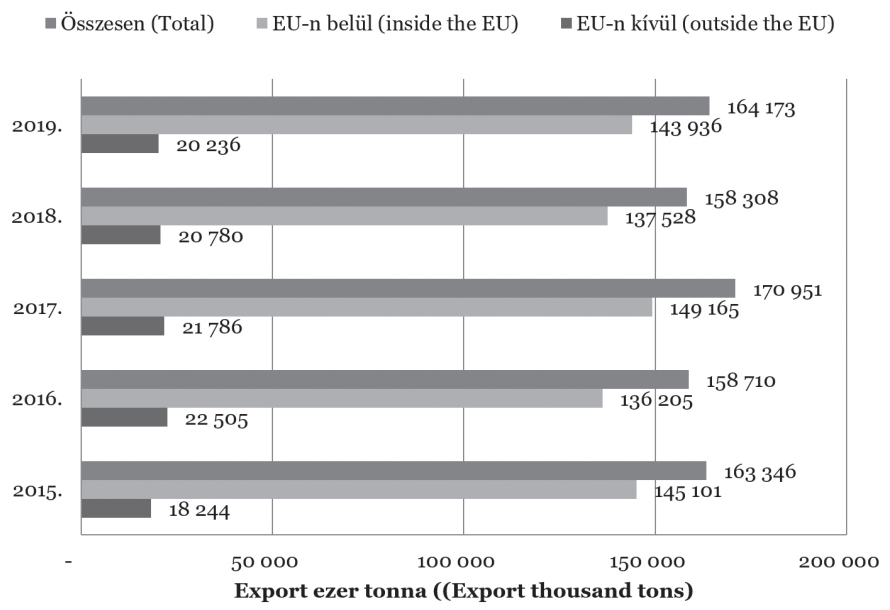

Az EU által exportált méz mennyisége 2015-2019 között (Honey Export by the EU Between 2015-2019)

Forrás (Source): Saját szerkesztés az Eurostat 2021 alapján (Authors'own compilation based on Eurostat 2021)

Az EU export döntő többségét a tagországok exportálják az unión belül, ennek értéke 2019-ben 143,9 ezer tonna méz volt. Az EU-n belül Belgium, Németország, Spanyolország, Magyarország és Lengyelország a legnagyobb mézexportőrök. Magyarország 2017-2018-ban a legnagyobb exportőr volt, hazánktól a legtöbb mézet Olaszország, Németország és Franciaország vásárolja (EUROSTAT, 2021).

Az EU-n belüli átlagos exportárak a 2015 és 2019 közötti időszakban alig változtak. A 2015. évi átlagár 3,54 EUR/kg, 2016-ban 3,55 EUR/ $\mathrm{kg}$, majd 2017-ben kismértékben emelkedett 3,65 EUR/kg árra. A 2018. évi 3,72 EUR/kgos átlagár volt a vizsgált időszak legmagasabb értéke, de 2019-re 8,3\%-kal csökkent. Az EU-n kívüli export átlagárához képest az EU-n belül, több mint 2 EUR/kg-mal alacsonyabb árak voltak tapasztalhatók.
Az Európai Unió 2019-ben összesen mintegy 339,8 ezer tonna mézet importált, a teljes uniós import körülbelül 60\%-a harmadik országokból származik, a fennmaradó rész az unión belüli tagországok közötti méz eladása. Az összes behozott méz mennyisége 2017-től az azt megelőző növekedés után - csekély mértékben csökkent (3. ábra).

Mézből az uniós önellátás mértéke $60 \%$ körül mozog, így mézfogyasztásának csaknem 40\%-át harmadik országból kell beszereznie. Az Unió legnagyobb beszállítója Kína, Ukrajna, valamint Argentína és Mexikó (PÁLYI, 2020).

Az EU-n kívüli, harmadik országokból beszerzett méz lényegesen olcsóbb, 2018-ban kevéssel 2 EUR/kg fölött alakult az átlagos import ár (EB, 2019). 
3. ÁBRA

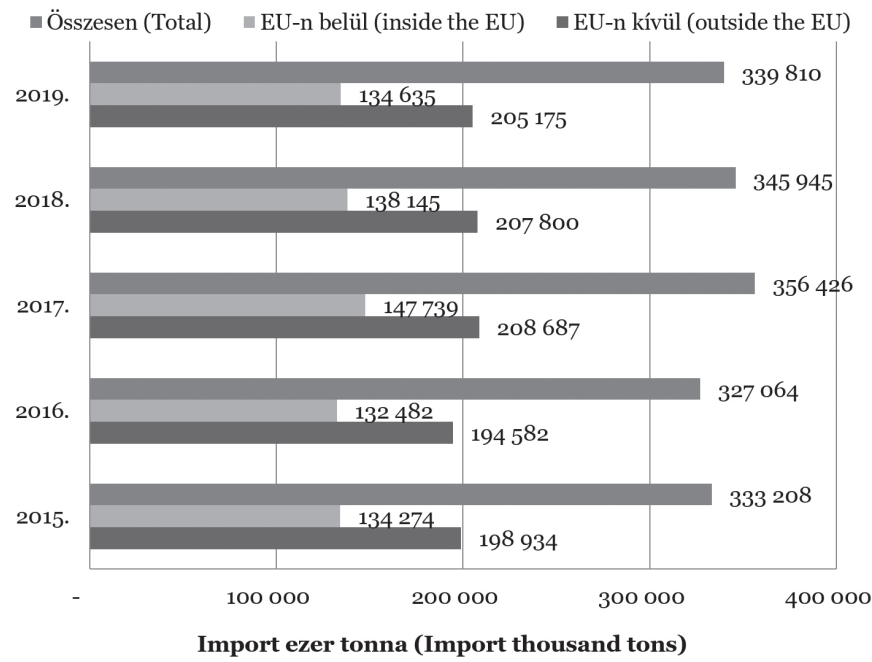

Az EU által importált méz mennyisége 2015-2019 között

FIG. 3

(Imported Honey by the EU Between 2015-2019)

Forrás (Source): Saját szerkesztés az Eurostat 2021 alapján (Authors'own compilation based on Eurostat 2021)

\subsection{A magyar méhészeti ágazat jellemzői - Characteristics of the Hungarian Beekeeping Sector}

A méhészet a magyar mezőgazdaságon belül egy sajátos helyzetű, kis volumenü, de nemzetközi jelentőségú ágazat. A méhészeti ágazat 2017. évi adatok szerint a mezőgazdaság bruttó termelési értékének 1,3\%-át adta (SZABÓ, 2020).

A méhészet Magyarországon is számos ökológiai és szocioökonómiai szerepet tölt be (NAGY, 2007). Magyarországon kifejezetten kedvezőek a természeti adottságok a méhészet szempontjából. Viszonylag hosszú a mézelő növények virágzási időszaka, amely alatt a méhek nektárhoz juthatnak. Az ország nagy kiterjedésű akácerdőkkel rendelkezik, amely a magyar méhészet legfontosabb méhlegelője (BLASKÓ et al., 2011). A magyar akácméz különlegességét igazolja, hogy 2014 óta szerepel a Hungarikumok gyưjteményében.

Az adatok alapján megállapíthatjuk, hogy 2016-ban volt a legtöbb méhészet hazánkban (23,9 ezer), ami 2018-ra 6,3\%-os visszaesést produkált. A méhcsaládok száma 2017-ben volt a legmagasabb, 1,253 millió. A méhegészségügyi felelősök szerint 2018-ban 1,237 millió méhcsalád volt, melyet 22,5 ezer méhtartó gondozott, az éves átlagos méhsűrüség 13,3 méhcsalád $/ \mathrm{km}^{2}$ volt. 2019-ben már csak 1,206 milliós méhcsaládszámot és 21,2 ezer méhész volt a nyilvántartásban, az éves átlagos méhsürüség 12,9 méhcsalád/ $\mathrm{km}^{2}$ (OMME, 2020). Ha az elmúlt 20 évet tekintjük, akkor elmondható, hogy a méhészetek száma 30\%-kal, a méhcsaládok száma 50\%-kal emelkedett hazánkban (BROSS, 2020).

A hazai méhészeti ágazat erőteljesen kiszolgáltatott a külföldi piacoknak, mivel a megtermelt méz nagy része exportálásra kerül (elsősorban az EU más tagországai számára), a hivatalos úton Magyarországra importált mézek aránya nem számottevő (ORAVECZ et al., $2020_{a}$ ).

A hazai fogyasztók nagymértékben árérzékenyek, a hazai mézfogyasztás mintegy 90\%-a lakossági fogyasztás, a méz további 10\%-át az ipar (sütödék, konzervgyárak, gyógyszertárak stb.) használja fel (BLASKÓ et al., 2011).

A mézexport mértéke 2019-ben az elmúlt 10 évet tekintve a harmadik legnagyobb menynyiség volt, a KSH adatai szerint 21 ezer tonna. A legtöbb mézet Olaszország vásárolja, melyet Németország követ, majd Franciaország és Ausztria. Ez a négy ország az összes magyar mézexport 78\%-át teszi ki. Az Unión kívül legnagyobb mennyiségben Japánba irányul a mé- 
zeladás. Az elmúlt 5 évben a belga export több mint tízszeresére, a spanyol körülbelül hétszeresére, a lengyel export pedig ötszörösére emelkedett (BROSS, 2020 ).

\section{ANYAg ÉS MódSzer - MATERIAL AND METHOD}

Az elemzés során felhasznált adatok a Faostat, az Eurostat, a Magyar Méhészeti Nemzeti Program és a KSH adatbázisaiból származnak. Ezekhez társult a témához kapcsolódó, aktuális kutatási eredmények és a releváns szakirodalom összegyűjtése. Ezeket a kutatások, adatbázisokból származó eredmények alapozták meg a méhészet helyzetelemzésének elkészítését. Miután elvégeztük az alapos szekunder háttérelemzést, a szakirodalomban a leggyakrabban használt helyzetelemzési módszert, a SWOT-analízist választottuk. A SWOT-analízis több lépcsőből áll, elsőként az ágazat erősségeinek, gyengeségeinek, lehetőségeinek, és veszélyeinek számbavétele történik meg.

Az erősségek a vizsgált szervezetben a rendelkezésre álló erőforrásokat és kedvező belső feltételeket jelentenek. Gyengeségként ezeknek pont az ellenkezőjét, vagyis hiányzó erőforrásokat és kedvezőtlen belső adottságokat lehet megjelölni. A lehetőségek esetében olyan kedvező külső feltételekről van szó, amelyek pozitív irányba befolyásolhatják az adott szervezethelyzetét, míg a veszélyek alatt a kedvezőtlen külső feltételrendszer kerül kifejtésre (SZŐLLŐSI és SZƯCS, 2015). A négy kategória számbavétele után következik a SWOT analízis második lépése, a SWOT 2 mátrix elkészítése, amely már túlmutat a helyzetfeltáráson. Jelen kutatás ezt még nem tartalmazza, de a cikk megírása után további célunk a helyzetfeltárás folytatása, és a SWOT 2 (vagy TOWS) mátrix elkészítése, mely a hazai méhészet stratégiai lehetőségeit tartalmazza.

A kvalitatív adatfelvételt egyéni interjúk keretében valósítottuk meg, amely során félig strukturált vezérvonalat alkalmaztunk (HOFFMANN et. al., 2000; MALHOTRA, 2005). A módszertan kiválasztásánál fontos szempont volt, hogy a lehető legtöbb primer információhoz juthassunk, így esett a választásunk az interjúra. Ennek elvégezéséhez összeállítottunk egy kérdéssort, mely a későbbiek során segítette az interjúk lefolytatását. A személyes megkérdezés jó lehetőséget biztosított ahhoz, hogy a méhészettel és az ezzel foglalkozó szakemberekkel, a mindennapi feladataikkal, problémáikkal, lehetőségeikkel megismerkedhessünk. Az interjúalanyok kiválasztásánál azt tartottuk szem előtt, hogy olyan vállalkozókat keressünk fel, akik méretüket tekintve eltérőek, egy kisebb 25 méhcsaláddal rendelkező méhész, illetve egy 150-160 méhcsaláddal rendelkező nagyobb méhész segítségével bepillantást nyerhetünk a vállalkozások múködésébe. Az interjúkon elhangzottak alapján képet kaphattunk a tevékenységükről, feladataikról, valamint a kapcsolódó szakmai kérdésekről. Az tanulmányban ez a két méhészet kerül elemzésre. Az egyik termelő nagyüzemi szinten folytatja a termelést, ahol a méhész főállásban dolgozik, 156 méhcsaláddal rendelkezik, a kaptárait és a kereteit saját maga készíti el. Egy 48 és egy 54 családos méhészkonténerrel, és 54 családos állóméhészettel folytatja a tevékenységét, Nagy-Boczonádi keretek használata mellett. Méztermelése akác-, napraforgó- és repcemézre terjed ki, mint főtermékei. Melléktermékként propolisz termeléssel is foglalkozik. Méheit vándoroltatja az akác, a napraforgó és a repce virágzásához igazítva.

A kisebb üzemmérettel termelő csak kiegészítő tevékenységként végzi ezt a tevékenységet, 25 méhcsaláddal. A kaptárokat és a kereteket is saját maga készíti. Termelése akác- és napraforgómézre korlátozódik le. Vándorló termelést folytat a nagyobb hozam elérése érdekében. A vándorlásokhoz általában nagyobb teherbírású szállítójármüvet bérel.

A méhészek valamennyi munkafolyamatban saját maguk is részt vesznek, kizárólag a pergetéskor foglalkoztatnak alkalmi munkavállalókat. A kisebb termelő esetén családtagok is segítenek a pergetéseknél, de nekik nem számol el munkabért. A termelők hasonló fajlagos költség és jövedelmezőségi mutatókat mutatnak, az ágazat speciális helyzetére visszavezethető okok miatt, vagyis a többi mezőgazdasági ágazattal szemben, az üzemméretből fakadó előnyök a jövedelmezőségben nem jelentősek, és kis üzemmérettel is kiváló jövedelemkiegészítő lehetőség.

A vizsgált méhészetek kérték az anonimi- 
tásukat, így személyes adataikról nem áll módunkban többet megosztani. Mindkét termelő széleskörü szakmai ismerettel rendelkezik, melynek több éves méhészkedési tapasztalatukra vezethető vissza. Mindkét méhész krajnai méhekkel termelnek és egyik termelő sem tagja semmiféle termelői integrációnak, amely esetleg segítené az értékesítést. Mindkét termelővel kapcsolatban személyes megkereséssel történt az adatgyưjtés 2020. október-novemberben.

\section{EREDMéNyeK - Results}

A szakirodalmi áttekintést alapul véve, és a mélyinterjúk alapján, elkészítettük a méhészeti ágazatra vonatkoztatott helyzetelemezést, amelyet az 1. táblázatban egy SWOT-mátrix segítségével összefoglaltunk. Összegyưjtöttük a méhészetre jellemző erősségeket, gyengeségeket, lehetőségeket, és veszélyeket. Az Erősségek között az első, hogy hazánk éghajlata a méhek életére kedvező. Természeti adottságai alapján az egész ország területe alkalmas a méhészkedésre, viszont a méhészetek és a méhcsaládok megyénként történő megoszlása igen nagy számbeli különbségeket mutat, ami az egyes országrészek eltérő természeti, éghajlati adottságaiból, a méhészeti hagyományok eltérő jellegéból adódhat. A méhészek, hogy minél többfajta mézet termelhessenek és növeljék bevételeiket, a méhlegelőkért az ország egész területén évente többször is vándorolnak. Egész Európában Magyarországon van a legkiterjedtebb, összefüggő erdőségeket alkotó akácfa állomány, a hazai erdő állomány egyötöde akác, ráadásul nagyobb részben tiszta állományú akácerdő. A méztermelés szempontjából fontos növények más-más időpontban virágoznak, a méhészek ezt figyelembe véve tervezik meg a vándorlást. Napjainkban a főhordást az akác adja Magyarországon. A Magyarországon előállított mézek közül világszerte a legkeresettebb és legismertebb a Hungarikum minősítéssel rendelkező akácméz. A magyar akácméz egyedi, kiváló minőségű termékünk, az egyike azon kevés élelmiszeripari terméknek Magyarországon, mellyel a nemzetközi piacokon az élmezőnybe tartozunk. Azonban sajnálatos, hogy az uniós kiskereskedelemben elvétve találkozhatunk olyan kiszerelt akácmézzel, amely cím- kéjéről a fogyasztó egyértelműen tudja, hogy magyar akácmézet vásárol. Más országokból származó akácmézzel keverik össze, így ezek elegye adja az unióban akácmézként árusított mézek összességét. Az Európai Unióban évente átlagosan megtermelt 250 ezer tonna mézból Magyarország 10\%-kal részesedik. Fajtamézekről akkor beszélünk, amikor a méz készítéséhez használt nektár túlnyomó része a megnevezés szerinti növényről származik, ez lehet: akácméz, hársméz, napraforgóméz, repceméz, gesztenyeméz, fenyőméz, levendulaméz, facéliaméz, selyemkóróméz, aranyvesszőméz, medvehagyma méz, hajdinaméz, édesharmat méz. További mézkülönlegességeink: lépesméz, virágporos méz, propoliszos méz. Ez a széles szortiment különösen a belföldi értékesítésben jelent komoly lehetőségeket, de az export piacokon is előnyt jelent. Magyarországon az Országos Magyar Méhészeti Egyesület (OMME) adatai szerint kb. 20 ezer méhész és mintegy 1,2 millió méhcsalád gondoskodik a méztermelésről, amely évente, az időjárás függvényében 15-30 ezer tonna mézet jelent. A magyar méhészeti ágazat szerkezetét illetően elmondható, hogy a méhészek leginkább kistermelői keretek között, kisszámú méhcsaláddal, mellékfoglalkozásként méhészkednek, viszonylag alacsony vagy közepesen gépesített technológiával, így magas fenntartási költségekkel (NAGY 2007; DUDÁS, 2015). A hazai méhészek jelentős része hobbi méhész és/vagy kiegészítő jövedelemszerzési lehetőségként végzi ezt a tevékenységet.

Az ágazat szakmai közéletét és szakmai érdekképviseletét az OMME látja el, mely magas szakmai színvonalon végzi a munkáját. Egyaránt jó kapcsolatokat ápol a szakminisztériummal és a Nemzeti Agrárgazdasági Kamarával. A támogatás rendszer kidolgozása során figyelembe vették és a jövőben is figyelembe veszik az OMME véleményét.

Napjainkban az egyik legfóbb gyengeség hazánkban a rendkívül elmaradott méhészeti technikai színvonal. A méhészeti termelés, mint mezőgazdasági tevékenység elsősorban a háztartásellátó, illetve őstermelő típusú termelés körébe tartozik. Nem igazán alakult ki a méhészeti tevékenységet támogató háttéripar sem. Mára nincs megteremtve a folyamatos fejlesztéshez, a fejlett, korszerű méhészeti 
technológiához szükséges eszközrendszer. Ez a hiányosság azt eredményezte, hogy minden méhész a maga útját járta saját eszközellátása érdekében. Ezért nemcsak kiegészítő eszközökben, hanem a kaptár típusaikban is nagyon különböznek egymástól. Hazánkban az alkalmazott kaptártípusokat két nagy kategóriába sorolják (fekvőkaptár és rakodókaptár), azonban ha a két típuson belül vizsgáljuk a kaptártípusokat, akkor számos változat megtalálható, mely tükrözi, hogy nem alakult ki egységes nézőpont, hogy melyik kaptártípus a legmegfelelőbb a hazai viszonyokhoz (NAGY, 2007). A méhcsaládok által megtermelt méz menynyiségét nagyban befolyásolja, hogy vándoroltatjuk-e a családokat. A fajtamézek előtérbe kerülésével (akác, napraforgó, facélia, hárs, stb.) vándorlás nélkül nem lehet megfelelő mennyiségü fajtamézet termelni. Megfigyelhető, ahogyan emelkedik a méhcsaládok száma, úgy nő azoknak az aránya, akik saját - esetleg bérelt - tehergépkocsit vagy utánfutót használnak, tehát élnek a vándoroltatás lehetőségével. A méhészkedéssel döntő részben férfiak foglalkoznak, és ezen belül is főként az idősebbek.

A méhészetek jellemzően tőkehiányosak. Kevesen rendelkeznek 150-200 méhcsaládot meghaladó állománnyal, mely méret már fedezhetné az esetleges beruházási költségeket. A 150 méhcsaládot meghaladó méhészetek száma 2000 és 2010 között az összes méhészet 10\%-át sem érte el (DUDÁS 2015). Az ágazatban problémát jelent, hogy a méhészek majdnem fele már több mint 20 éve méhészkedik, tehát a szakma elöregedése tapasztalható. Nem jellemző a megfelelő képzettség sem, a méhészek 76,1\%-ának nincs méhész szakképesítése (NAGY, 2007).

A gyengeségek között említhetjük még a hiányos kommunikációt a növény-, illetve gyümölcstermesztő és a méhész között. A kommunikáció megkönnyítése érdekében napjainkra szükségessé vált egy GPS alapú, országosan elérhető alkalmazás (méhlegelő elektronikus nyilvántartó rendszer), amellyel napra készen nyomon követhető a méhészeti tevékenység.

További gyengeség a termelők kiszolgáltatottsága. A termelők többsége érdekérvényesítő képesség nélkül, diktált áron tudja csak eladni termését és az a meggyőződése, hogy a kereskedők visszaélnek kiszolgáltatott helyzetével. A termelők és a kereskedők között általában nincsenek szerződéses kapcsolatok (NAGY, 2007). Gyengeségünk még, hogy a belföldi mézfogyasztás relatíve alacsony, átlagosan fejenként mintegy 90-100 dkg/fö/év (ugyan megduplázódott az elmúlt 15 évben), de még mindig alacsonynak tekinthető.

A magyar méhészeti ágazatra jellemző, hogy a termelés többszörösen meghaladja a szükségleteket. A megtermelt méz 80\%-a hordós kiszerelésben hagyja el az országot, mely nem hangsúlyozza a kiváló minőséget. Az országban maradt méz 40\%-át kiszerelő cégek a szupermarketekben, 60\%-át a méhészek közvetlenül a fogyasztónak értékesítik. Ez az arány az elmúlt évtizedben tolódott el a méhészek értékesítése felé és tart napjainkban is.

A lehetőségek között említhetjük, hogy a hazai méhészeti ágazatban jelenleg csak kevés múködő horizontális integrációról beszélhetünk, de a teljes vertikális integráció sem igazán valósul meg egy cégen, illetve cégcsoporton belül. Hazánkban mintegy 20 méhészeti szövetkezet múködik, de ezek a szövetkezetek alapvetően eltérnek a közös tulajdonon alapuló szövetkezeti formától, elsősorban közös értékesítésre, bizonyos anyagok, termékek és szolgáltatások közös beszerzésére alakultak.

A méz az egészségvédelem, a betegségmegelőzés szempontjából fontos élelmiszernek tekintendő (TAKÁCS et al., 2016). A méz népszerüsége Magyarországon töretlen, a méhészeti termékek iránti érdeklődés az utóbbi években növekedett, a mézfogyasztás a 2010. évi o,3 kg-ról 2018-ra o,8 kg-ra emelkedett, jelenleg 1 kg körül van. Összehasonlítva az uniós átlagos mézfogyasztással, amely 1,7 kg évente, még tartogat lehetőségeket a hazai piac. Az egy före eső évi mézfogyasztás Ausztriában 1,2 kg, Németországban 1,3 kg, Svájcban 1,4 kg, Görögországban 1,5 kg (FAO 2019; AMC, 2021).

Egy 2019-es hazai kutatás eredményei is igazolják Lászlóffy korábbi eredményeit, mely szerint a fogyasztók mézről alkotott képe egyértelműen javult az elmúlt években, nőtt a mézfogyasztás, a fogyasztók egészséges és természetes édesítőszerként tekintenek a mézre (MEZÔNÉ és KOVÁCS, 2019). Így ha évente 10 dkg-mal emelnénk a fejenkénti fogyasztást már 1 ooo tonna hazai méz biztos piacra jutását lehetne biztosítani.

Veszélyforrásként említhető a globális klímaváltozás, mely leginkább az időjárási szél- 
sőségek gyakoribb megjelenését okozzák hazánkban. Ez befolyásolja a méhek rendszeres gyűjtőmunkáját, illetve a mézelő növények nektártermelését. Az időjárás sokszor változik, melyre a méhek érzékenyen reagálnak, ezért szinte minden évszakban védeni kell őket az időjárástól. TAKÁCS és OLÁH (2017) szerint a magas méhsürüség nem minden esetben jár gazdasági előnnyel, hiszen méhegészségügyi kockázatot rejt magában.

Komoly veszélyforrás a hazai méz piaci pozíciójára, hogy a méz nyomon követése - ami a magyar jogszabályok szerint itthon kötelező - az unióban nem mindenütt egyformán elvárás. A mézkereskedelem és feldolgozás terén hátrányt okoz, hogy a méz származásának megjelölésekor nem feltétlenül kell megjelölni a származási országot, elég csak EU és nem EU országok mézkeveréke megjelölést alkalmazni (TAMMA, 2017).

A két leggyakoribb hamisítási módszer a méz minőségét vagy az elnevezését érinti. A minőségi hamisításnál mézen kívüli anyagot (cukrot) adnak hozzá a mézhez, vagy a mézbegyüjtés túl korán megy végbe, amely alapján a végtermék állaga olyan fokban változik, hogy az már nem felel meg a méz definíciójának (PÁCZAY, 2018). Az EU-ban a méz „természetes, édes anyag, amelyet az Apismellifera (mézelő méh) állít elő növények nektárjából, amelyet összegyưjtenek, átalakítanak, dehidratálnak, tárolnak és méhsejtekben érlelnek meg." Ez a meghatározás kizárja az emberi beavatkozást a méhek érlelési és dehidratálási folyamatában (PÁCZAY, 2018; PÁLYI, 2020 ). A kínai meghatározás szerint viszont a dehidratálási folyamatot nem a méhek végzik, hanem az mesterségesen, aktív dehidratálási folyamat során történik. Becslések szerint a Kínában előállított méz igen nagy százaléka (90\%) a Kínában elfogadott meghatározásnak felel csak meg, amelyet aztán így importálnak az EU-ba. Az elmúlt években több mézhamisítással kapcsolatos eljárást is kidolgoztak, amellyel nagyobb menynyiségű, de gyenge minőségű mézet állítottak elő több országban is: India, Mianmar, Tajvan, Thaiföld, Ukrajna voltak (PHIPPS, 2016).

Ezt a helyzetet nehezíti a jelenleg érvény- ben lévő címkézési szabályozás hiányosságai, mellyel nem követhető nyomon a megvásárolt méz pontos származási helye, illetve, hogy pontosan milyen mézek keverékét tartalmazza. Az uniós szabályozás szerint (Méz irányelv) jelenleg - amennyiben a méz több országból származik - a címként nem kell feltüntetni (egyszerüsített jelölés) a származási országot és az összetétel arányát (csupán EU-s vagy nem EU-s ország mézkeveréke).

A mézhamisítás kapcsán az Apimondia, a méhészegyesületek nemzetközi szövetsége részletes szakmai állásfoglalást adott ki 2019-ben. Ez az állásfoglalás minden mézpiaci szereplő számára útmutatóként szolgál arra vonatkozóan, hogy naprakész információval rendelkezzenek a méztisztaságot és eredetiséget érintő legújabb fejleményekről. A mézhamisítás a piacon globális méretekben is kritikus helyzetet teremt, amely befolyásolja mind a méz árát, mind az egyéb méhészeti folyamatokat. Az állásfoglalás kizárólag a Codex Alimentarius (1981) leírásában szerepló követelményeknek megfelelő mézet tartja elfogadhatónak. Javaslatai a következőek: a méhésztársadalom, a fogyasztók, a forgalmazók és csomagolók informálása, a nemzetközi és nemzeti hatóságokkal, kereskedőkkel, intézményekkel való együttmúködés, az élelmiszer-hamisítás szankcionálása a helyi törvényeknek megfelelően, harmadik felek bevonása a standardok igazolására, a méz visszakövetése egészen a méhészig (PÁLYI, 2020 ).

A hazai méhészeti termelés jelenleg a honosnak tekintett pannon méhvel ${ }^{1}$ folyik Magyarországon, melynek értékmérő tulajdonságai nagy összhangot mutatnak a hazai méhlegelők nyújtotta lehetőségekkel. A veszélyek között meg kell említeni, hogy hazánkban őshonos krajnai méh, pannon változat egyik tulajdonsága a rajzási hajlam felerősödése, mely termelést sok esetben negatívan befolyásolja, főként akácvirágzás idején (TAKÁCS és OLÁH, 2017).

A méztermés mennyisége 2019-re csökkentô tendenciát mutat, azonban ez a kibocsátás csökkenés nem jár együtt a mézpiacon az árak növekedésével, ahogyan azt a kereslet-kínálat

1A NÉBIH Állattenyésztési Igazgatóság 2012. augusztus 21-én kelt 02.5/2297-2/2012 számú határozata szerint pedig az addig krajnaiként (Apis mellifera carnica) elismert méhünk neve a továbbiakban pannon méh, amelyet önálló fajtának tekintünk (Magyar Méhtenyésztők Országos Egyesülete, 2019) 
törvénye indokolná. Azokban az országokban, ahonnan az EU importál mézet, annak ára folyamatosan csökken. A Kínából érkező méz átlagára 1,24 EUR/kg, az Ukrajnából érkező méz ára 1,69 EUR/kg volt, Argentínából 2,28 EUR/ kg, Mexikóból 2,56 EUR/kg átlagáron érkezett méz (PÁLYI, 2020; EUROSTAT, 2021). Az Európai Unióban egy kg méz előállítása átlago- san 3,9 EUR-ba kerül. Ezzel szemben a vegyes virágméz ára a tagországok közül Spanyolországban 2,57 EUR/kg-ra, Magyarországon 1,60 EUR/kg-ra, Romániában 1,47 EUR/kg-ra csökkent 2019-ben (PÁLYI, 2020 ). Tehát az európai méhészeknek jelen helyzetben versenyezniük kell a nagymértékü és olcsó harmadik országokból származó import mézekkel.

\section{TÁBLÁZAT}

TABLE 1

A minta összetétele (Composition of the Sample)

\begin{tabular}{|c|c|}
\hline Erösségek (Strengths) & Gyengeségek (Weaknesses) \\
\hline 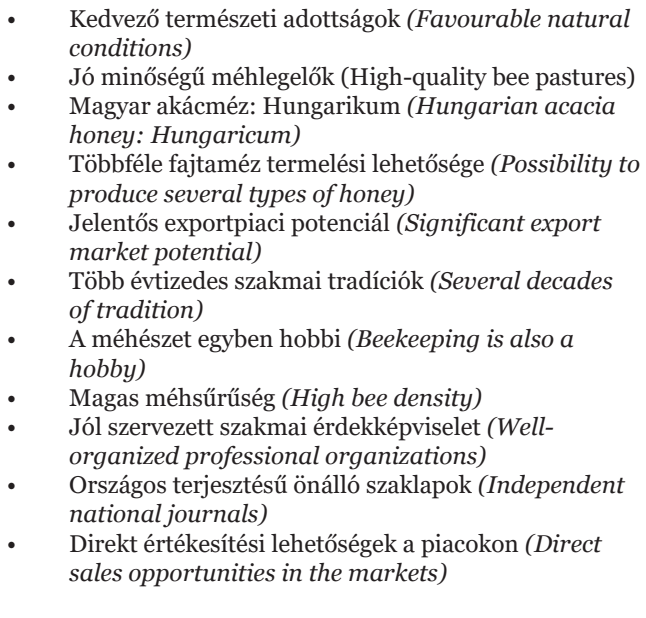 & $\begin{array}{l}\text { - Elavult technológiai színvonal, tőkehiány } \\
\text { (Old technological level, lack of capital) } \\
\text { A méhésztek 1/3-a nem vándoroltat » nincs kihasz- } \\
\text { nálva a fajtamézben rejlő potenciál (The 1/3 of } \\
\text { apiaries are not migratory » the potential of the } \\
\text { variety honey has not been exploited) } \\
\text { Alacsony a szakképesítéssel rendelkezó méhészek } \\
\text { száma, elöregedett a méhésztársadalom (The number } \\
\text { of professional beekeepers is low, beekeepers are } \\
\text { aging) } \\
\text { Hiányos kommunikáció a növénytermesztő és a } \\
\text { méhész között (Lack of communication between the } \\
\text { plant grower and the beekeeper) } \\
\text { Magas fajlagos élómunka ráfordítás, alacsony felvá- } \\
\text { sárlási ár (High specific labor costs, low purchase } \\
\text { price) } \\
\text { - Szezonális munka jelleg (Seasonal work) } \\
\text { Termelői kiszolgáltatottság a kereskedőknek } \\
\text { (Producer exposure to traders) } \\
\text { Alacsony színvonalú a hazai mézfogyasztás } \\
\text { (Hungarian honey consumption is low) }\end{array}$ \\
\hline
\end{tabular}

\begin{tabular}{|c|c|}
\hline Lehetőségek (Opportunities) & Veszélyek (Threats) \\
\hline $\begin{array}{l}\text { - Integrációt, együttmúködést támogató környezet } \\
\text { (Environment that supports integration and } \\
\text { cooperation) } \\
\text { - Közösségi szintű marketing tevékenységek } \\
\text { (Marketing activities in community level) } \\
\text { Egészségtudatos táplálkozás térnyerése, a méz elő- } \\
\text { térbe kerülése (Health-conscious diet spread, honey } \\
\text { came to the fore) } \\
\text { - Növekvő kereslet a kézműves termékek iránt } \\
\text { - } \quad \text { Nöowing demand for handicraft products) } \\
\text { Növekvó tendenciájú mézfogyasztás a fóbb export- } \\
\text { piacainkon (Increasing honey consumption in our } \\
\text { main export markets) }\end{array}$ & $\begin{array}{l}\text { - } \quad \text { Globális klímaváltozás miatt nő az időjárási szélső- } \\
\text { ségek előfordulása » pl. akácvirág elfagyása (Due } \\
\text { to global climate change, the weather extremes is } \\
\text { increasing » e.g. freezing of acacia flowers) } \\
\text { - Újabb méhbetegségek, a kártevők rezisztenciája a } \\
\text { gyógyszerekre, vegyszerekre (New diseases, pest } \\
\text { resistance to drugs, chemicals) } \\
\text { - } \quad \text { Növényvédőszerek elterjedése (Spread of pesticides) } \\
\text { Hamisított mézek térhódítása az európai piacokon } \\
\text { (Fake honey expansion in European markets) }\end{array}$ \\
\hline
\end{tabular}

Forrás (Source): Saját szerkesztés, 2021 (Authors'own compilation, 2021) 


\section{KÖVETKEZTETÉSEK ÉS}

\section{JAVASLATOK - CONCLUSIONS AND}

PROPOSALS

A nemzetközi és európai mézpiacot számos tényező együttes hatása befolyásolja, mint a méhészeti ágazat támogatottsága (egyre fontosabbá válik), az árfolyamok alakulása, a klímaváltozás, a gazdasági és természeti környezet, az időjárás, a méhegészségügyi helyzet, a méhlegelők mennyiségi és minőségi változása, valamint a fogyasztók mézigénye, a fogyasztói szokások változása (ORAVECZ et al., 2020 $)$.

Az Európai Unióban a vizsgált időszakban az összes méztermelés csökkenő tendenciát mutat, néhány százalékos visszaeséssel. A méhcsaládszám és a méhészek száma 2017 óta emelkedésnek indult, azóta fokozatosan emelkedik. Az uniós mézexport ebben az öt évben ingadozó tendenciát mutat, azonban az import 60\%-át kitevő EU-n kívülről érkező méz menynyisége 2017 óta - az addigi emelkedés után - kis mértékben csökkent (1,5\% körüli arányban).

A méztermelőknek és más érintetteknek világszerte és Európában egymáshoz hasonló, mézpiacot kedvezőtlen irányba alakító folyamatokkal kell szembe nézniük.

A legnagyobb probléma nemzetközi szinten is a mézhamisítás, valamint az utóbbi években kialakult súlyos méhegészségügyi helyzet, a terjedő méhbetegségek, méhpusztulások (ORAVECZ et al., 2020 ). Az egyes tagországokban elvégzett tesztelési eljárások eltérőek, a hamisítók is gyorsan tanulnak és állnak elő új módszerekkel (TAMMA, 2017). A szakmai szervezetek minden méztermelő országban törekednek az ágazat megsegítésére, a méhészeti tevékenység folytatásához szükséges feltételek javítására. Számos javaslatot fogalmaztak meg nemzetközi szinten is. Az Apimondia állásfoglalása a széles körű együttműködést, jogszabály sértés esetén komoly szankciókat, monitoring rendszer múködtetését, a méhészek folyamatos szakképzését, informálását hangsúlyozza (PÁLYI, 2020 ).

$\mathrm{Az}$ Európai Professzionális Méhészek Egyesülete (EPBA) az Európai Gazdálkodók és Európai Termelőszövetkezetek (Copa-Cogeca) szervezetével együttmúködve dolgoznak az uniós méz nagybani értékesítésének a világ többi mézétól való elválasztásáért, a mézhamisítás ellen, a méhek védelméért a növényvédó szerek ellen, valamint a mézcímkézésre vonatkozó szabályok szigorítása érdekében (PÁLYI $2020_{\mathrm{a}}$ ).

A Bizottsági jelentés többek között olyan címkézési szabályozás kidolgozását javasolja, mely a méhek szempontjából felelősségteljes termelési rendszer alkalmazását tanúsítja (EB, 2019).

A mézhamisítás mellett kiemelkedő fontosságú tényező a méhek egészségét veszélyeztető betegségek jelenléte, terjedése. A méhek számára nem sok engedélyezett gyógyszer áll rendelkezésre, ezért hangsúlyos lenne az informatikai technológiák kiterjesztése a méhészetekben, amelyek elősegíthetik a méhek betegségeinek könnyebb felismerését (EB, 2019).

A megfelelő számbavételi rendszerek alkalmazása szintén kiemelkedően fontos, mivel a fő mutatószámok a méhészetek, méhcsaládok száma, valamint az általuk realizált mézhozam alakulása alapján elemezhető a méztermelés (ORAVECZ et al., 2020) . A Mézjelentés kiemeli, hogy közös uniós szabványok szükségesek a méhészek számára, az EU-ban jelenleg több módszerrel is meghatározhatják a tagországok a méhkaptárak számát, illetve a méhészek számát illetően csak az egyesületekbe szerveződött termelőkről tartanak nyilván adatokat (OMME, 2020).

A méhészeti ágazat helyzetének javítása érdekében alkotta meg az EU a nemzeti méhészeti programok rendszerét, mely különbözó méhészeti intézkedéseket tartalmaz tagországi szinten. A nemzeti programoknak alapvető célja, hogy javítsák a méhészeti termékek unióbeli termelésének és forgalmazásának általános feltételeit, különböző támogatási intézkedéseket és a hozzájuk rendelt támogatásokat tartalmazzák, elosztásának alapja az egyes tagországokban található méhkaptárak száma (EB 2019; ORAVECZ et al., 2020).

Kiemelkedően fontos a méhészetek modernizálása, technológiai színvonalának növelése, a rendelkezésre álló kutatási eredmények elemzése, értékelése, és az ezek alapján tett megállapítások fényében kell intézkedéseket tenni az ágazati válság kezelésére (MAGYAR MEZŐGAZDASÁG, 2019). Kizárólag a méhcsaládszám 
emelése nem jelent fajlagos jövedelemnövekedést (TÓTH, 2019). Amennyiben a termelési költségek a nyomott árak mellett csak növekednek, akkor a termelők a tevékenység felhagyása mellett fognak dönteni, így csökkenthet a méztermelés és az ágazat hosszú távú jövőjét biztosító generációváltás elmaradhat.

A méhek és méhészek érdekében fenntartható mezőgazdasági gyakorlatok kialakítására, alkalmazására van szükség, valamint a biodiverzitás szellemében kialakított vidékfejlesztési intézkedések megvalósítására (EB, 2019). Az ágazat stabilizálása esetén (mézhamisítás elleni fellépés, árak normalizálása, hatékony méhegészségügy) elérhető a méhészkedés hosszú távú fenntarthatósága, annak ökológiai jelentősége (megporzás, ökoszisztéma, biodiverzitás) megvédhető és a vidék népességmegtartó szerepe a méztermelő országokban erősödhet.

\section{6. ÖSSZEFOGLALÁS - SUMMARY}

Jelenleg tanulmány célja az volt, hogy bemutassa az ágazat helyzetét, kihívásait. Megállapítható, hogy a méhészeti ágazat több olyan problémával küzd, amely hatással van a termelők termelékenységi és jövedelmezőségi helyzetére, függetlenül az üzemméretétől vagy a területi elhelyezkedésétől. Ezek közül kiemelendő a méz uniós összehasonlításban relatíve alacsony felvásárlási ára, a munkaerő rendelkezésre állása, a szaktudás alacsony szintje, számos kórokozó és kártevő megjelenése és a globális klímaváltozás.

$\mathrm{Az}$ egyik legnagyobb probléma, hogy az európai méhészeknek versenyezniük kell a nagymértékü és olcsó harmadik országokból származó import mézekkel. A mézhamisítás, az elégtelen szabályozás okozta helyzet alapvető problémát okoz az európai és nemzetközi mézpiacon, az árak alakulására pedig torzító hatással van. Az uniós szintű méhész érdekképviseleti szervek, egyes tagállamok, tagállami mezőgazdasági kamarák, valamint a gazdálkodó mezőgazdasági vállalkozók és szövetkezetek érdekvédelmi szervezete hivatalosan is felléptek ez ügyben az Európai Bizottságnál (PÁCZAY, 2018), hiszen hiába emelkedik a méhcsaládok száma, ha közben csökken az ágazat jövedelmezősége (MAGYAR MEZŐGAZDASÁG, 2019).
A hazai méhészeti tevékenységre vonatkozó SWOT analízis alapján megállapítható, hogy számos erősséget rejt magában az ágazat (pl: a hungarikummá vált akácméz, kiváló méhlegelők, OMME stb.).

A fennálló gyengeségeket (pl: alacsony mézfogyasztás, gyenge marketing tevékenység, elavult technológia stb.) és veszélyeket (pl: klímaváltozás, méhbetegségek, hamisított mézek nagy aránya stb.) nem szabad figyelmen kívül hagyni, és törekedni kell arra, hogy a lehetöségeket (pl: integráció, kézmúves termékek további népszerüsége és a méz pozitív élettani hatása) minél hamarabb „megragadhassa” az ágazat.

\section{IRODALOMJEGYZÉK - REFERENCES}

AMC: Mézkampány. 2021. http://www.amc. hu/mezkampany/ (Letöltés dátuma: 2021.02.16.)

Árváné, V. G.: A mézpiac marketing szempontú elemzése különös tekintettel a fogyasztói és vásárlói magatartásra. Doktori (Phd) értekezés. Debrecen, 2011

Blaskó, B. - Cehla, B. - Kiss, I. - Kovács, K. - Lapis, M. - Madai, H. - Nagy, A. Sz. - Nábrádi, A. - Pupos, T. Szőllősi, L. - Szúcs, I.: Állattenyésztési ágazatok ökonómiája. 2011. URL: https:// regi.tankonyvtar.hu/hu/tartalom/ tamop425/OO10_1 A_B ook_19_ Allattenyesztesi_agazati_okonomia/ch15. html (Letöltés dátuma: 2021.02.09.)

Bross, P.: Méhészetek, méhcsaládok száma 2019. Méhészet. 2020 68 (6) 4.

Bross, P.: Mézexport 2019. Méhészet. 2020 68 (7) 4 .

Dudás, R.: Egy méhészeti vállalkozás megvalósíthatósága. Szakdolgozat. Miskolci Egyetem Gazdaságtudományi Kar Vezetéstudományi Intézet. 2015

EB: A Bizottság jelentése az Európai Parlamentnek és a Tanácsnak a méhészeti programok végrehajtásáról. Brüsszel, 2019.12.17. 2019. https://ec.europa.eu/ transparency/regdoc/rep/1/2019/HU/ COM-2019-635-F1-HU-MAIN-PART-1. PDF. (Letöltés dátuma: 2021.01.19.) 
EP: Az Európai Parlament 2018.03.01-jei állásfoglalása az EU méhészeti ágazata előtt álló kihívásokról. 2018. https://www. europarl.europa.eu/doceo/document/TA8-2018-0057_HU.html (Letöltés dátuma: 2021.01.16.)

Európai Tanács: A Tanács 2001/110/ EK Irányelve (2001.12.20.) a mézről. 2001. https://eur-lex. europa.eu/legal-content/HU/TXT/ PDF / ? u ri = CELEX: 02001 L O 110 20140623\&from=EN. (Letöltés dátuma: 2021.01.18.)

Eurostat: EU Trade Statistics. 2021. https:// trade.ec.europa.eu/access-to-markets/ en/statistics?includeUK=true (Letöltés dátuma: 2021.01.30.)

FAO: Largest Consumers of Honey. CA4657EN/1/o5.19. 2019. www.fao. org>ca4657en>ca4657en (Letöltés dátuma: 2021.02.10.)

Faostat: Livestock Primery. 2021. http:// www.fao.org/faostat/en/\#data/QL (Letöltés dátuma: 2021.02.10.)

Hoffmann, M. - Kozák, Á. - Veres, Z.: Piackutatás. Műszaki Könyvkiadó, Budapest, 2000. 79-84.

KSH: Agrár idősorok és cenzusok. Tej-, tojás-, gyapjú-, toll- és méztermelés (1857-) 2019. https://www.ksh.hu/docs/hun/ agrar/html/tabl1_5_3_4.html (Letöltés dátuma: 2021.02.10.)

\section{Magyar Méhtenyésztők Országos} Egyesülete: Pannon méh teljesítményvizsgálati kódex 2019. https:// portal.nebih.gov.hu/documents/10182/ 43858 / Pannon + m \% C $3 \%$ A 9 h + t e l je s \% C $3 \%$ A D t m \% C $3 \%$ A 9 n y viz s g \% C $3 \%$ A 1 lat i k\%C3\%B3dex+2019.pdf /dbee9a 9b-oa6ff454-04ee-31b962925d1d (Letöltés dátuma: 2021.02.17.)

Magyar Mezőgazdaság: Az európai méhészek védelmében - Támogatott magyar javaslat Brüsszelben. 2019. https:// magyarmezogazdasag.hu/2019/11/19/ az-europai-meheszek-vedelmebentamogatott-magyar-javaslat-brusszelben (Letöltés dátuma: 2021.02.16.)

Malhotra, N. K.: Marketingkutatás. Akadémia Kiadó Zrt., Budapest, 2009
Mezőné, O. T. - Kovács, I.: A hazai termelői mézek és méhészeti termékek iránti fogyasztói bizalom kvalitatív vizsgálata. Jelenkori társadalmi és gazdasági folyamatok. 2019. 14 (2) 79-89. DOI: https://doi.org/10.14232/jtgf.2019.2.7989

Nagy, I.: A méhészeti termelés technológia, gazdasági, társadalmi összefüggéseinek vizsgálata. Doktori (Phd) értekezés. Mosonmagyaróvár, 2007

OMME: Magyar Méhészeti Nemzeti Program Környezetterhelési Monitoring vizsgálat 2019-2020. Oláh Nyomdaipari Kft., Budapest, 2020

Oravecz, T. - Mucha, L. - Illés, B. Cs.: A magyar méhészeti ágazat elmúlt 20 éve Termelési alapok. Gazdálkodás: Scientific Journal on Agricultural Economics. 2020 а 64 (5) 435-451. DOI: https://doi. org/10.22004/ag.econ.305812

Oravecz, T. - Mucha, L. - Totth, G. - Illés, B. Cs.: A hazai méztermelés helyzete és változása 2000-2017 között. Társadalmi és gazdasági folyamatok elemzésének kérdései a XXI. században. Szegedi Tudományegyetem. Szeged, 2020 DOI: https://doi.org/10.14232/ tgfek21sz.20

Páczay, Gy. B.: Valódi mézet az európai fogyasztóknak! Agrár-és Környezetjog. 2018. (25) 229-243. DOI: https://doi. org/10.21029/JAEL.2018.25.213

Pályi, K.: Az EU mézpiacának helyzetértékelése. Méhészet. 2020 68 (6) 26-27.

Pályi, K.: Apimondia: állásfoglalás a mézhamisításról 3. rész. Méhészet. $202 \mathrm{O}_{\mathrm{b}}$ 68 (5) 24-25.

Papp, L. (szerk.): A helyi termékértékesítés tapasztalatai Európában Leader térségek közötti együttmúködési program Mecseki Mézes Körút c. projekt keretében készült tananyag. Landart Kft., 2015

Patel, V. - Pauli, N. - Biggs, E. - Barbour, L. - Boruff, B.: Why Bees Are Critical for Achieving Sustainable Development. Ambio. 2021. 50 49-59. DOI: https://doi. org/10.1007/s13280-020-01333-9 
Phipps, R.: Meddig zuhan a méz ára? 1. (Fordította: Bross, P.). Méhészet. 2016. 64 (2) 10-11.

Szabó, A.: Infojegyzet Méhészet, mézpiac. Képviselői Információs Szolgálat. Budapest, 2020. https://www.parlament. hu / documents / $10181 / 4464848$ / Infojegyzet_2020_20_Meheszet\%2C_ mezpiac.pdf/89762c54-686a-05513086-b6b8257236c7?t=1587631137603 (Letöltés dátuma: 2020.09.24.)

Szőllősi, L. - Szűcs, I.: Az üzleti tervezés alapjai. Debreceni Egyetem, 2015

Takács, M. - Madai, H. - Oláh, J.: A magyar akácméz versenyképességének helyzete 2015-ben. In: Takácsné György, K. (szerk.). XV. Nemzetközi Tudományos Napok: Innovációs kihívások és lehetőségek 2014-2020 között: a tudományos napok publikációi., Károly Róbert Főiskola, Gyöngyös, 2016. 15191525 .
Takács, M. - Oláh, J.: A pannon méh. Ôstermelő gazdálkodók lapja. 2017. 21 (2) 87-91.

Tamma, P.: Honeygate: How Europe is Being Flooded with Fake Honey. EURAKTIV. com 2017.09.08. 2017. https://www. euractiv.com/section/agriculturefood/news/honeygate-how-europe-isbeingflooded-with-fake-honey/ (Letöltés dátuma: 2021.04.30.)

Tóth, Gy.: A magyar méhészet Achilles-sarkai. Méhészet. 2019. 67 (1) 16-18.

Tóth, Gy.: Klímaváltozás és nektártermelés. Méhészet. 2020. 68 (11) 26-27. 